\title{
DETECTION OF BEETLE DAMAGE IN FORESTS BY X-RAY CT IMAGE PROCESSING ${ }^{1}$
}

\author{
Paulo Estevão Cruvinel ${ }^{2}$, João de Mendonça Naime³, Miguel Borges ${ }^{4}$, Álvaro Macedo ${ }^{3}$ e Aijun Zhang ${ }^{5}$
}

\begin{abstract}
Some beetle species can have devastating economic impacts on forest and nursery industries. A recent example is Anophophora glabripennis, a species of beetle known in the United States as the "Asian Longhorrned beetle", which has damaged many American forests, and is a threat which can unintentionally reach south American countries, including Brazil. This work presents a new method based on X-ray computerized tomography (CT) and image processing for beetle injury detection in forests. Its results show a set of images with correct identification of the location of beetles in living trees as well as damage evaluation with time.
\end{abstract}

Key words: Forests, living trees, computerized tomography and injury detection.

\section{DETECÇÃO DE DANOS CAUSADOS POR BESOURO EM FLORESTAS COM PROCESSAMENTO DE IMAGENS DE TOMOGRAFIA COMPUTADORIZADA DE RAIOS X}

\begin{abstract}
RESUMO - Algumas espécies de besouros têm elevado impacto econômico em florestas e indústrias de móveis. Exemplo recente é aquele produzido pelo besouro Anophophora glabripennis, uma espécie conhecida nos Estados Unidos como Asian Longhorn, que tem produzido danos significativos em várias florestas americanas, representando uma ameaça que poderá encontrar transporte não-intencional para países da América do Sul, inclusive para o Brasil. Neste trabalho é apresentado um novo método com base no uso de tomografia de raios $X$ computadorizada $(C T)$ e processamento de imagens digitais para detecção de injúrias causadas por besouros em florestas. Os resultados mostram a correta identificação da localização de besouros em árvores vivas, como também fornecem uma avaliação do estrago temporal causado.
\end{abstract}

Palavras-chave: Florestas, árvores, tomografia computadorizada e detecção de injúrias.

\section{INTRODUCTION}

A wide variety of living organisms are in general transported from country to country every day, primarily as a result of trade. They include aquatic, air, and land organisms, generally known as stowaways. Although most of them cause little apparent damage, some have greatly altered major forest ecosystems in many parts of the world. An example is the Anophophora glabripennis, a beetle species having white spots on its body. Native to China, Japan, and Korea, the "Longhorned Beetle" is present in some regions of the United States. This beetle was probably introduced from China, via untreated wooden packing material used in international cargo (Milius, 1999). It belongs to the family Cerambycidae, whose sub-family Laminae species known as hardwoodborers, usually attacks living trees. The Anophophora glabripennis has an enormous destructive potential

1 Recebido para publicação em 18.7.2002.

Aceito para publicação em 9.9.2003.

2 Embrapa Agricultural Instrumentation, P.O.Box 741, 13560-970 São Carlos-SP, Brazil, and Center for Strategic Management and Studies, SCN Quadra 2, B1. A, Ed. Corporate Financial Center, 70712-900 Brasília-DF, Brazil; ${ }^{3}$ Embrapa Agricultural Instrumentation, P.O.Box 741, 13560-970 São Carlos-SP, Brazil. ${ }^{4}$ Embrapa Labex - USDA, ARS, Beltsville, Maryland 20705, USA. ${ }^{5}$ USDA, ARS Chemicals Affecting Insect Behavior Laboratory, BARC-W, Beltsville, Maryland 20705, USA. 
because it spends most of its larval life inside tree trunks or branches, and neither pesticides nor natural enemies capable of effectively controlling this pest have so far been identified. Larval boring in the trunk and large branches inhibits the vascular system of the trees, causing severe damage and eventually tree breakage and death (Cavey et al., 1998; Zang et al., 2000). This species, which has spread to some North American forests and nursery industries, had devastating economic impact. Efforts to control or eradicate this exotic species have led to removal and destruction of all trees showing attack symptoms in Chicago and New York City (Haack et al., 1996).

Because many pests brought by several exotic beetle species are associated with unprocessed wood packing materials used in international trade, or possibly even by other unknown agricultural ways, a set of different control techniques is being investigated in many parts of the world, but the challenge remains. In Brazil, for instance, researchers have applied sequential sampling for different attack levels to monitor Sirex noctilio (Penteado et al., 1998), and have developed a damage detection mapping program for Brazilian forests (Viana et al., 2002).

However, further research is needed in this area to find an adequate solution to be implemented in forestry and agriculture.

Within this context, and considering recent times, there has been a resurgence in gamma and X radiation applications to studies of some physical characteristics of wood and soils including density, mass attenuation coefficients, water content, and soil particle sizes (Crestana et al., 1985; Cruvinel et al., 1990; Macedo et al., 2000; Fioravanti \& Ricci, 1991; Lindgren et al., 1992; Pang \& Wiberg, 1998). This new interest could be traced to the phenomenal success of computerized X-ray tomography (CT) in both medicine and industry. Various recent studies have shown a potential for agricultural applications. Density is related to many anatomical and physical properties of wood and correlated to its quality. Density measurements are classically obtained by gravimetric or direct transmission gamma-ray methods. However, these methods only provide average density values without the information allowed by $\mathrm{CT}$ about anatomical characteristics, such as knots and insect presence, and wood quality.

R. Árvore, Viçosa-MG, v.27, n.5, p.747-752, 2003
This paper presents a new method for detecting beetle injury in forests by means of CT image processing technique.

\section{MATERIAL AND METHODS}

Hardware and software employed for tomographic measurements were organized by using a CT miniscanner and a portable CT scanner, both from Embrapa Agricultural Instrumentation Center, respectively presenting the following characteristics: ${ }^{241} \mathrm{Am}$ gamma ray source (with approximately $1.2 \times 10^{10} \mathrm{~Bq}, 300 \mathrm{mCi}$ ); $\mathrm{NaI}$ (Tl) scintillation detector; photomultiplier tube; single channel analyzer; counter and timer; mechanical sample positioning system with stepper motors; lead collimators for spatial resolution of about $1 \mathrm{~mm}^{2}$ (Cruvinel et al., 1990); ${ }^{137} \mathrm{Cs}$ gamma ray source (with approximately $1.1 \times 10^{9} \mathrm{~Bq}, 30 \mathrm{mCi}$ ); solid state detector; microcontrolled built-in single channel analyzer and counter; mechanical sample positioning system with stepper motors that allows rotation and translation of the source, and detector systems, which are assembled on a split ring that can be opened to encircle the sample under analysis; lead collimators for spatial resolution of about $2 \mathrm{~mm}^{2}$ (Naime et al., 1996).

Over the past 30 years, considerable interest has developed in problems of pattern recognition, pattern identification, and image processing with application to vision systems. This interest has created an increasing need for theoretical methods and experimental software and hardware for use in the design of dedicated vision systems (Giacinto et al., 1997). The developed method is new regarding its application, taking into account not only the application of CT technique, but also a dedicated image processing algorithm for beetle presence analysis in living trees, i.e., its spatial location and damage evaluation.

In order to evaluate the methodology for beetle pest detection in forests by means of CT image processing, a set of eight slices of Eucalyptus grandis W.Hill ex Maiden with $0.418 \mathrm{~g} / \mathrm{cm}^{3}$ density, and mass attenuation coefficients of $0.193 \mathrm{~cm}^{2} / \mathrm{g}$ and $0.083 \mathrm{~cm}^{2} / \mathrm{g}$, respectively, for $59.6 \mathrm{keV}$ and $662 \mathrm{keV}$ was prepared. Wood damage and density measurements were carried out by simulation of this prepared set of Eucalyptus grandis, having holes inside and a typical Coleoptera insect present in Brazil. The holes were drilled to simulate damage caused by this beetle species. Figure 1 illustrates an injury in living trees 
caused by the Anophophora glabripennis (Lingafelter, 1998). Gravimetric humidity of the wood samples was controlled by oven drying the samples at $110^{\circ} \mathrm{C}$ mass attenuation coefficient $\left(\mathrm{cm}^{2} / \mathrm{g}\right)$ of the wood samples was calculated using the linear attenuation coefficient $\left(\mathrm{cm}^{-1}\right)$, obtained pixel by pixel from CT images of the samples.

Figure 2 shows the algorithm for beetle detection by means of linear attenuation coefficient measurements on CT images outlined in block diagram form. The main procedure is entered following initialization of a tomographic image file, using a selection of first parameters for imaging measurement.

Control software allows selecting initial energy and pixel size, and programming of acquisition time interval for each projection and sensor scanning, data acquisition, average filtering, data linearization, and data storage on floppy disk. Data files are reconstructed off line and hold up to1600 pixels per image in ASCII format.

\section{RESULTS AND DISCUSSION}

Two tomographic series were carried out, respectively, for $59.6 \mathrm{keV}$ and $662 \mathrm{keV}$. In both cases, results were obtained by using the algorithm presented.

Figure 3 and 4 shows, respectively, CT images obtained from a simulated set of living trees having wood samples of Eucalyptus grandis with and without the

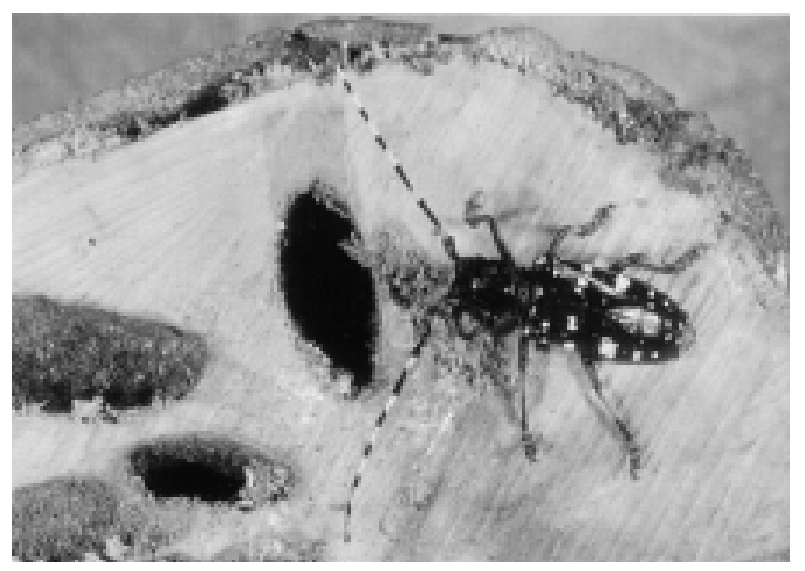

Figure 1 - I njury in living trees caused by the Anophophora glabripennis (Lingafelter, 1998).

Figura 1 - Danos causados em árvores vivas pelo Anophophora glabripennis (Lingafelter, 1998).
Coleoptera Dichotomius anaglipticus, a typical beetle present in Brazil, at energies of $59.6 \mathrm{keV}$ and $662 \mathrm{keV}$, respectively. Beetle presence can be observed and damage represented by holes inside the wood samples, by means of a density variation graphic.

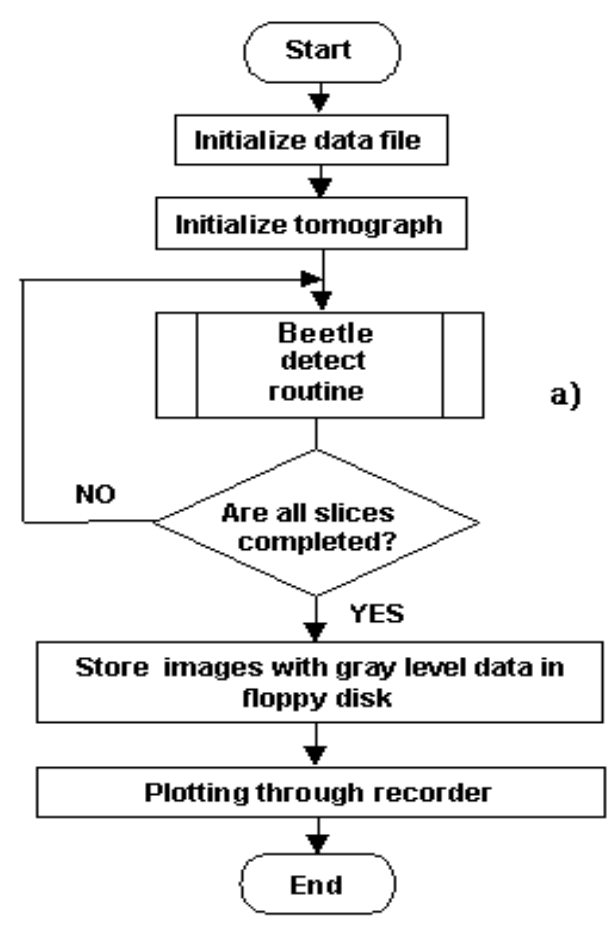

Figure 2 - (a) Algorithm outlined in block diagram form; (b) beetle measurement process outlined in block diagram form.

Figura 2 - (a) O al goritmo del ineado em diagrama deblocos e (b) processo de medida para besouro em diagrama de blocos.

Table 1 - Mass attenuation coefficient for eight different wood samples (after M acedo et al., 2000)

Quadro 1 - Coeficiente de atenuação de massa para oito diferentes amostras de madeira (após Macedo et al., 2000)

\begin{tabular}{|c|c|}
\hline Species & $\begin{array}{c}\text { Mass attenuation coefficient } \\
\left(\mathrm{cm}^{2} / \mathrm{g}\right) \text { at } 59.6 \mathrm{keV}\end{array}$ \\
\hline Eucalyptus dunnii & 0.178 \\
\hline Eucalyptus saligna & 0.181 \\
\hline Eucalyptus deanei & 0.179 \\
\hline Eucalyptus grandis & 0.193 \\
\hline Eucalyptus pilularis & 0.176 \\
\hline Aroeira & 0.179 \\
\hline Grevilea & 0.183 \\
\hline
\end{tabular}


Table 1 shows the mass attenuation coefficient for eight different wood samples (Macedo et al., 2000). Also, at $59.6 \mathrm{keV}$, the beetle Coleoptera Dichotomius anaglipticus mass attenuation coefficient was $0.209 \pm 0.043 \mathrm{~cm}^{2} / \mathrm{g}$.

If exotic pests are detected relatively early, aggressive eradication programs can prevent large-scale infestation. Only through rigorous inspection, regulation, and

(a) Wood sample \# 1 without beetle

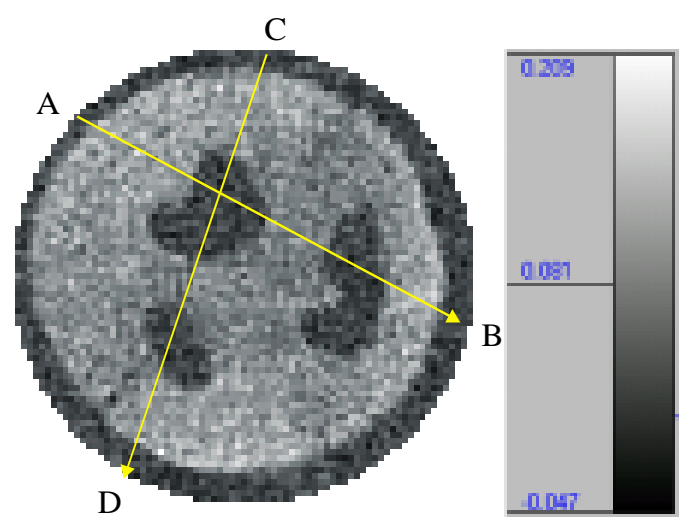

Density Variation $(\mathrm{AB})$

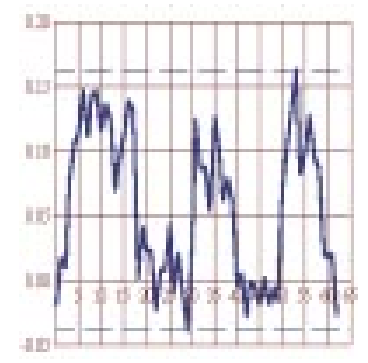

Density Variation (CD)

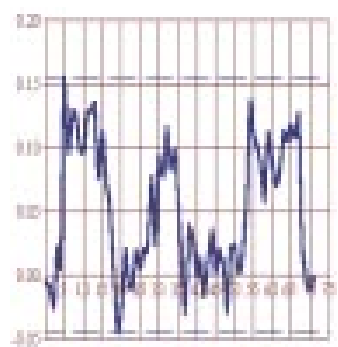

management can the threat these exotic insects represent be minimized. If institutions are not prepared to make efforts to safeguard the ecosystem, it will be undermined in resources and biological diversity.

Wood losses were also verified in this analysis, being approximately equal to $23.5 \%$ for sample \#1 and to $38.8 \%$ for sample \#2.

(b) Wood sample \# 1 with one Coleoptera Dichotomius anaglipticus

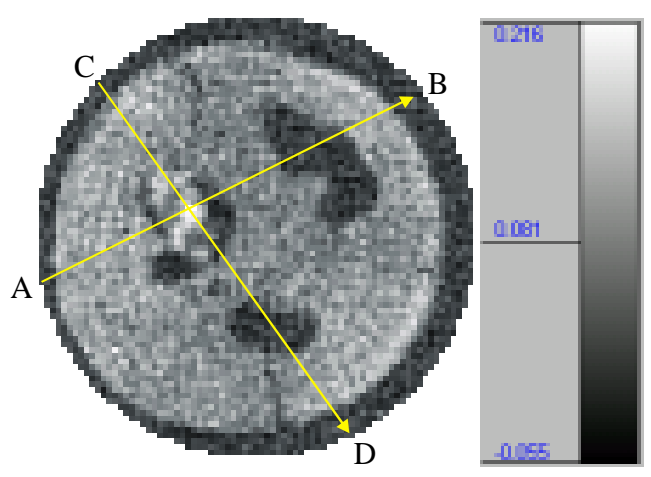

Density Variation $(\mathrm{AB})$

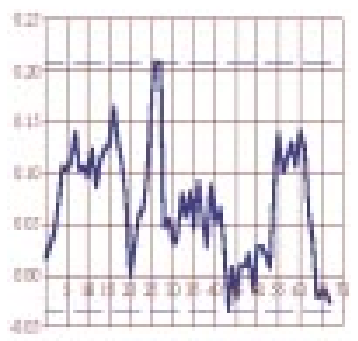

Density Variation (CD)

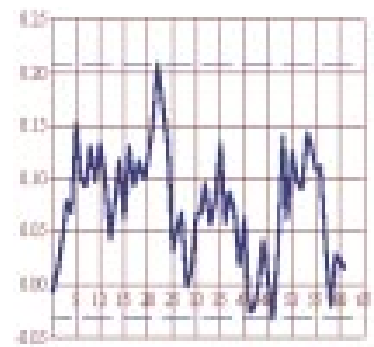

Figure 3 - (a) and (b) CT images at energy of $59.6 \mathrm{keV}$, obtained from the simulated set of wood samples with holes simulating damage; (b) image where one Coleoptera Dichotomius anagl ipticus is visualized.

Figura 3 - (a) e (b) imagens CT obtidas na energia de 59,6 keV de um conjunto de amostras de madeira com buracos que simulam danos e (b) imagem onde é visual izado um Col eoptera Dichotomi us anaglipticus. 
(a) Wood sample \# 1 with one beetle Coleoptera Dichotomius anaglipticus beetle
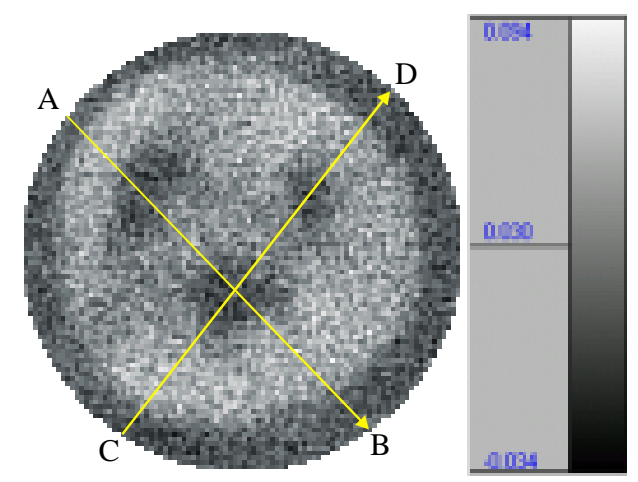

Density Variation (AB)

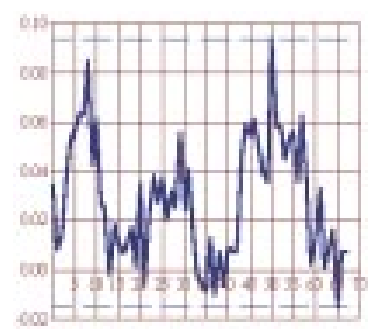

Density Variation (CD)

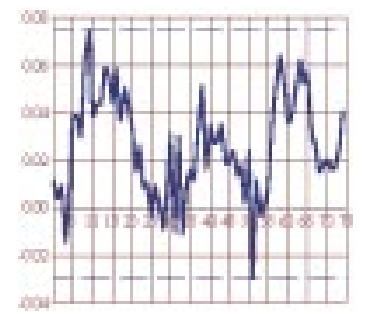

(b)Wood sample \# 3 with two beetles Coleoptera Dichotomius anaglipticus beetles

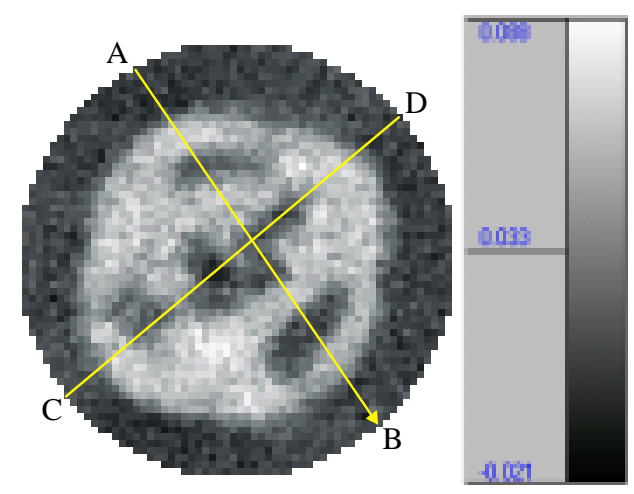

Density Variation (AB)

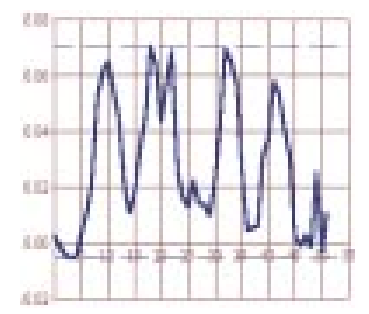

Density Variation (CD)

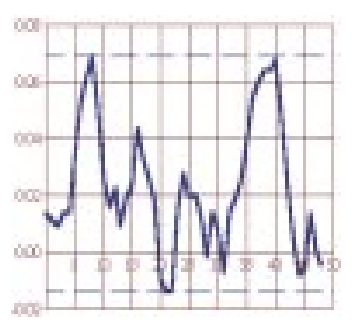

Figure 4 - (a) and (b) CT images obtained at energy of $662 \mathrm{keV}$ from the simulated set of wood samples with holes simulating damage; (b) image obtained from a wood sample containing one Coleoptera Dichotomius anagli pticus (it is not possible to observe the beetle at such energy).

Figura 4 - (a) e (b) imagens CT obtidas na energia de $662 \mathrm{keV}$ de um conjunto de amostras de madeiras com buracos que simulam danos e (b) imagem obtida de uma amostra de madeira que contém um Col eoptera Dichotomi us anagli pticus (nesta energia não é possível visualizar o besouro).

The first limitation on CT images can be overcome when the direct Bremsstrahlung radiation from the $\mathrm{X}$-ray tube is employed; however, this affects the precision of the reconstruction algorithm and image contrast. Several solutions have been presented to solve the second problem. In this work, the original back projection algorithm developed in transmission tomography was selected. This implies knowledge of matrix attenuation coefficient of incident radiation energy. Results were satisfactory using the original version of the back projection algorithm without any attenuation correction. It is clear that this approximation works as were when $\mu \mathrm{x}_{\max }<<1$, where $\mathrm{x}_{\max }$ is the stem diameter of the living trees. Beetles can be observed on the images 
obtained with incident energy of $59.6 \mathrm{keV}$. On the other hand, the images obtained with an incident energy of $662 \mathrm{keV}$ did not allow such analysis, i.e., it was not possible to get an adequate contrast resolution.

\section{CONCLUSIONS}

This paper presents an innovative methodology for beetle pest detection in forests by means of CT image processing. Using the laboratory CT scanner with energy of $59.6 \mathrm{keV}$, the contrast resolution was much better for the CT images, i.e., $43.5 \%$ in comparison with CT images obtained under $662 \mathrm{keV}$. However, the portable CT scanner, usable under field conditions, allows replacement of its $662 \mathrm{keV}$ radioactive source by another having $59.6 \mathrm{keV}$, and the required image contrast resolution for beetle analysis can be reached. Results also show the suitability of the developed method in terms of performance and reliability, i.e., its usefulness as a shortterm technical aid, based on image processing, to help safeguard economic and ecological systems not only in Brazil but also worldwide.

\section{ACKNOWLEDGMENTS}

The work reported in this paper was supported in part by grants from the Brazilian Enterprise for Agricultural Research (Embrapa) and the America Research Service (ARS), USDA, USA. The authors would like to thank the first Labex coordinator Dr. Sílvio Crestana for support. The first author also received a partial grant from $\mathrm{CNPq}$.

\section{BIBLIOGRAPHIC REFERENCES}

CAVEY J. F. et al. A new exotic threat to North America hardwood forests: an Asian Longhorned beetle, Anophophora glabripennis (Coleoptera: Cerambycidae). I. Larval, Description and Diagnosis. Proceedings of the Entomological Society of Washington, v. 100, n. 2, p. 373 381,1998 .

CRESTANA, S.; MASCARENHAS, S.; POZZI-MUCELLI R. S. Static and dynamical three dimensional studies of water in soil using computed tomography scanning. Soil Science, v. 140, n. 5, p.326-32, 1985.

CRUVINEL, P. E. et al. X-ray and gamma ray computerized minitomograph scanner for soil science. IEEE Transactions on Instrumentation and Measurement, v. 39, n. 5, p. 745750, 1990 .

R. Árvore, Viçosa-MG, v.27, n.5, p.747-752, 2003
FIORAVANTI, M.; RICCI R. Computerized tomography for wood density measurement: experimental research and methodologies. Accad. Ital. Sci. For., v. 40, p. 57-59, 1991.

GIACINTO, G.; PAOLUCCI, R.; ROLI F. Application of neural network and statistical pattern recognition algorithms to earthquake risk evaluation. Pattern Recognition Letters, v. 18 , n. $11-13$, p. $1353-1362,1997$.

HAACK, R. A. et al. Anophophora glabripennis: a new tree infesting exotic Cerambycidae invader. Newsletter of the Michigan Entomological Society, v. 41, n. 2-3, p. 1-3, 1996.

LINDEGREN, O. et al. Non-destructive wood density distribution measurements using computed tomography. Holz als Roh - und Werkst., v. 50, p. 295-299, 1992.

LINGAFELTER S. W. Starry Sky Beetle - The latest Amityville horror. Agricultural Research, Beltsville Area Research Highlights, 1998. p. 52.

MACEDO, A. et al. Soil management impact and wood science - Recent contributions of Embrapa agricultural Instrumentation Center using CT images. In: Advances in Agricultural Tomography, São Carlos, Ministry of Agriculture and Food Supply, EMBRAPA, 2000. p. 44-54.

MILIUS, S. Son of long-horned beetle. Science News, v. 155 , p. $380-382,1999$.

NAIME, J. M. et al. Portable cat scanner applied to collapsible soil studies. In: INTERNATIONAL CONFERENCE ON PHYSICS AND INDUSTRIAL DEVELOPMENT, BRIDGING THE GAP, 1996, Belo Horizonte. . Anais... Belo Horizonte: 1996. p. 327-331.

PANG, S.; WIBERG, P. Model predicted and CT scanned moisture distribution in a Pinus radiata board during drying. Holzals Roh - und Werkst., v. 56, p. 9-14, 1998.

PENTEADO, S. R. C.; OLIVEIRA E. B. I.; TADEU E. Aplicação da amostragem seqüencial para monitoramento dos níveis de ataque de Sirex noctilio em povoamentos de Pinus taeda. In: CONGRESSO FLORESTAL

LATINOAMERICANO 1., 1998, Valdívia, Chile. Anais... Valdívia: IUFRO, 1998. v. 1. p. 21-24

VIANA F. M.; OLIVEIRA Y. M. M.; ROSOT M. A. D. Desenvolvimento de um programa mapeamento aeroexpedito para detecção e mapeamento de danos florestais no Brasil. In: EVENTO DE INICIAÇAO CIENTÍFICADA EMBRAPA FLORESTAS, Colombo. Anais... Colombo: EMBRAPA FLORESTAS, 2002 (CD Rom). (Embrapa Florestas, Documentos, 70)

ZHANG, A., et al. Stimulatory beetle volatiles for the Asian Longhorned beetle, Anophophora glabripennis. Journal of Chemical Ecology, v. 1, p. 17-25, 2000. 